\title{
INVESTIGATING THE PROPERTIES OF DENTAL COMPOSITES
}

\section{PREISKAVA LASTNOSTI KOMPOZITA ZA ZOBNE ZALIVKE}

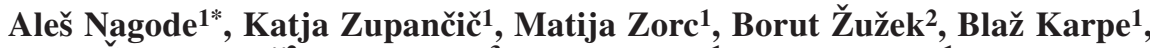 \\ Barbara Ština Batič ${ }^{2}$, Borut Zorc ${ }^{3}$, Borut Kosec ${ }^{1}$, Milan Bizjak ${ }^{1}$, Alenka Pavlič ${ }^{4}$ \\ ${ }^{1}$ University of Ljubljana, Faculty of Natural Sciences and Engineering, Aškerčeva c. 12, 1000 Ljubljana, Slovenia \\ Institute of Metals and Technology, Lepi pot 11, 1000 Ljubljana, Slovenia \\ ${ }^{3}$ Welding Institute, Ptujska ulica 19, 1000 Ljubljana \\ ${ }^{4}$ University of Ljubljana, Faculty of Medicine, Vrazov trg 2, 1000 Ljubljana, Slovenia
}

Prejem rokopisa - received: 2019-06-13; sprejem za objavo - accepted for publication: 2019-02-12

\author{
doi:10.17222/mit.2019.128
}

The purpose of this work was a characterisation of the microstructure, certain mechanical properties (compressive strength, hardness) and thermal characteristics of a restorative dental composite. Three composite testing samples were made in the shape of a cylinder. Regarding the composite polymerisation, two routes were performed:

1) applying multiple layers from which the final sample was composed and curing each of the layers separately, and

2) applying the whole volume of the composite sample and then curing the surface across the whole sample.

The surfaces of both samples and the microstructure analysis of the composite material were performed with a scanning electron microscope (SEM) and an attached EDXS detector. Then the compressive strength, hardness and thermal conductivity were also measured. Based on the performed tests, it was found that the analysed dental restorative composite had applicable studied properties, and the composite meets the clinical requirements for use as a dental restorative material.

Keywords: dental composite, scanning electron microscopy, mechanical properties, thermal conductivity

Namen pričujočega dela je bila karakterizacija mikrostrukture izbranih mehanskih lastnosti (tlačne trdnosti in trdote) in termičnih karakteristik obnovitvenega dentalnega (zobnega) kompozita. Avtorji so izbrali tri preizkusne vzorce kompozita cilindrične oblike. Glede na polimerizacijo kompozita so izbrali dva načina njegove izdelave: 1) z uporabo več plasti od katere je bil zadnji vzorec izdelan tako, da je bila vsaka plast obdelana in sestavljena ločeno in 2) z uporabo celovitega kompozitnega vzorca, ki je bil nato obdelan preko celotne površine. Površino obeh vrst vzorcev so pregledali z vrstičnim elektronskim mikroskopom (SEM) in analizirali s prigrajenim EDXS detektorjem. Nato so izmerili še njuni tlačni trdnosti trdoti in toplotno prevodnost. Avtorji na osnovi izvedenih preiskav ugotavljajo, da imata obe vrsti obdelave dentalnega kompozita za obnovo uporabne lastnosti in da izpolnjujeta tako klinične zahteve kot uporaben material za dentalno obnovo.

Ključne besede: dentalni kompozit, vrstična elektronska mikroskopija, mehanske lastnosti, toplotna prevodnost

\section{INTRODUCTION}

In dentistry, a variety of materials are used in order to replace the missing dental tissues, e.g., particular metals and alloys, ceramics, and various adhesive materials, among which composites have an important place. Each composite is a combination of different materials in which the individual constituents preserve their physical identity; nevertheless, the overall properties of a composite are superior to those of the individual components. ${ }^{1-4}$ The cured dental composite material shows a better combination of characteristics than any individual substance, constituting the composite. Indeed, the introduction of a resin-based dental composite around the middle of the last century represented a major step forward in restorative dentistry. Currently, resin-based composites are probably the most ubiquitous materials available in dentistry. There are a huge variety of dental clinical applications for composite materials: as dental restorative (filling) materials, luting agents, material for endodontic posts and cores, indirect composite restor-

*Corresponding author's e-mail:

ales.nagode@omm.ntf.uni-lj.si (Aleš Nagode) ations (veneers, inlays and onlays), and fibre-reinforced bridges.

Each composite consists of a mixture of two or more distinctive materials. Resin-based dental restorative materials are typically constituted of three major components: an organic resin, inorganic fillers and a coupling agent, which ensures good adhesion between the organic resin and the inorganic filler particles. The coupling agent enables the fillers and the resin to be strongly bonded to each other. Coupling agents, i.e., silanes (e.g., $\gamma$-MPTS or $\gamma$-methacryloxypropyltriethoxylane), are incorporated into the resin. Further, a polymerisation inhibitor (e.g., hydroquinone) needs to be included in order to prevent unwanted premature polymerisation. On the other hand, the resin activator must also be added to achieve the polymerisation when desired. Dental composite materials harden though a process of polymerisation of the monomeric resin matrix. This process can be induced by either chemical curing or induced via visible-light curing. Nowadays, polymerisation of the vast majority of dental composites takes place with visible-light-curing, activated with a 
specific molecule photo-initiator (e.g., camphorquinone), which creates reactive species when exposed to light.

The resin is the chemically active component of dental composite; initially liquid monomers are converted into rigid polymers by radical addition reaction polymerisation. After its inventor, the resin is commonly referred to as Bowen's resin. The monomers are of different viscosities. The presence of individual monomers influences the properties of a composite. Of all monomers, usually the larger proportion has a highly viscous Bis-GMA (bisphenol-A-glycidyldimethacrylate). Bis-GMA, which derives from the reaction of bisphenol-A and glycidyl methacrylate, is the most commonly used monomer in dental composites. UDMA (urethane dimethacrylate) is another highly viscous monomer that is frequently used in dental composites. As the addition of even small amount of filler to those highly viscous fluids would result in a very rigid composite, low-viscous monomers need to be added; e.g., MMA (methyl methacrylate), EDMA (ethylene glycol dimethacrylate) and TEGDMA (triethylene glycol dimethacrylate). ${ }^{3}$ Nevertheless, the addition of these monomers has also some unwanted consequences. With a higher proportion of TEGDMA the polymerization shrinkage increases as well as the tensile strength, while the flexural strength decreases. ${ }^{5}$

On the other hand, the mechanical properties of a composite material are predisposed principally by the inorganic filler particles (i.e., quartz, ceramic, silica). The composition and the size of the filers determine the mechanical properties of the composite, such as hardness and compressive strength. With the inclusion of glass in a polymer, the increases the stiffness. An increasing content of fillers also decreases the shrinkage, thermal linear expansion and water absorption, and increases the compressive and tensile strength, modulus of elasticity and wear resistance. The required aesthetic features (e.g., colour, translucency and fluorescence) are also provided by the filler particles.

According to the size of the filler particles, dental composites can be classified into macro-fillers (with usual size of 10-20 $\mu \mathrm{m}$ and the largest particle size of 40 $\mu \mathrm{m})$ and micro-fillers (with an average particle size of $0.2 \mu \mathrm{m}$ and a range of $0.01-0.05 \mu \mathrm{m}$ ). Composites with macro-fillers are very strong, but satisfactory final polishing of their surface is not feasible, while the composites with micro-filler can be polished to a very smooth surface finish but they are much weaker due to the relatively low filler content. Hybrid (or blended) composites contain filler particles of an average size of $15-20 \mu \mathrm{m}$ and also a small amount of colloidal silica, with a particle size of 0.01-0.05 $\mu \mathrm{m}$. Small-particle hybrid composites, with an average particle sizes of around $1 \mu \mathrm{m}$ and $0.1-6.0 \mu \mathrm{m}$, allow a highly polished surface finish. Additionally, in order to increase the filler loading, fillers of two (or more) complementary particle sizes are incorporated (e.g., mid-filler with particles of size of $1-10 \mu \mathrm{m}$ and mini-filler with particles of size of $0.6-1.0 \mu \mathrm{m}$ in a combination with particles of size of $40 \mathrm{~nm}$ ). More recently, micro-hybrid and nano-filled composites have been developed, containing filler particles of micro- and nano-scale, respectively. There are two distinct types of nano-filled composites: entirely nano-filled and nano-hybrids. Nano-hybrids include nanoparticles, larger particles (of sizes similar to those in micro-hybrid composites) and may also contain prepolymerized resin fillers, similar to those found in the micro-filled composites. ${ }^{2}$

In recent decades, the use of dental composites has increased tremendously. ${ }^{6}$ Dental composites exhibit good aesthetic and mechanical properties (e.g., non-solubility, volumetric stability, resistance to forces and wear, and with low thermal conductivity). Composites are also tasteless, and nontoxic. Last but not least, on X-ray images the dental composites can be easily distinguished from the hard dental tissues and other surrounding structures. To achieve radiopacity, bismuth, barium, strontium, titanium dioxide, quartz or zircon is incorporated into the glass filler particles of dental composite materials. More recently, ytterbium has also been added to the composites in order to achieve radiopacity.

In a mouth, teeth and materials that are used for the substitution of hard dental tissues are exposed to various specific conditions; these materials must have the ability to successfully endure these changes. ${ }^{7}$ Predictable polymerisation and a suitable curing time makes dental composites very useful in everyday dental practice. Indeed, dental composites can be used as restorative materials in the anterior region as well as in the posterior region for smaller and medium-sized fillings. ${ }^{8-10}$

The aim of this study was to analyse the microstructure constituents, to determine some crucial mechanical properties (compressive strength and hardness) and to measure the thermal properties of the nano-filled restorative composite material.

\section{EXPERIMENTAL PART}

In the study we analysed the microstructure, hardness, compressive strength and thermal properties of the nano-ceramic dental composite Ceram.X One Universal (Dentsply DeTrey, Konstanz, Germany). Analyses were made on three cylindrical samples. Though, due to the nature of the investigative methods, the volumes of the composite samples were much greater than the volumes of dental fillings.

For the microstructure characterisation and compressive strength measurements, two testing samples were prepared in glass tubes with an inner diameter of $8.65 \mathrm{~mm}$. In the glass tube, the composite was applied and cured; in the first sample, it was applied in increments of up to $2 \mathrm{~mm}$ of height in multiple layers and each polymerised separately, and in the second sample, it was applied in one bulk of composite, and then 


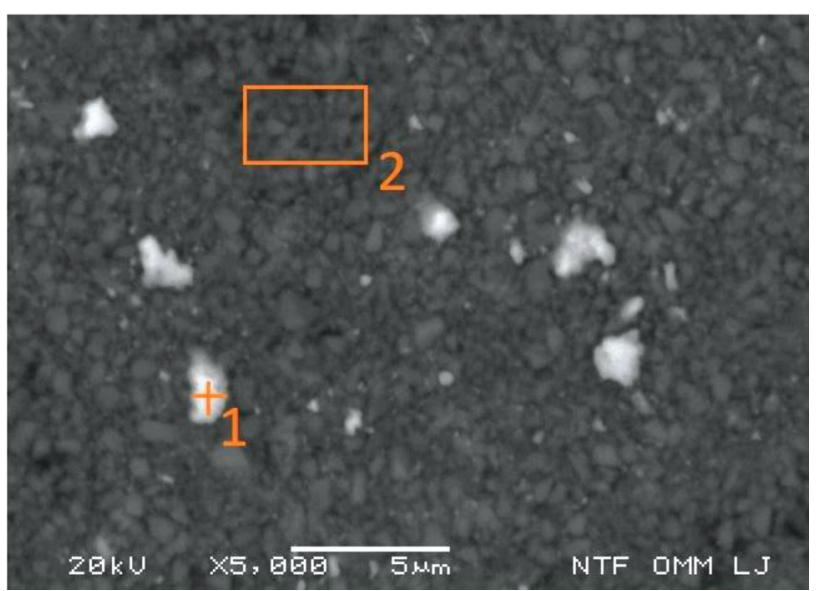

Figure 1: Microstructure of dental composite (BEI)

polymerized over the surface of the whole sample. When the composite samples were cured, the glass tubes were scattered. The heights of those two composite cylinder samples were $11.7 \mathrm{~mm}$ and $13.41 \mathrm{~mm}$.

For the thermal and hardness measurements, composite cylinder samples of diameter $30 \mathrm{~mm}$ and height $10 \mathrm{~mm}$ were prepared. The sample was cured in layers of approximately $2 \mathrm{~mm}$ of thickness; the surface of each layer was covered with nine separate illuminations that lasted for 30 seconds each.

For the polymerisation of composite cylinder samples we used dental light-curing unit (Bluephase G2 Universal LED Curing Light, Ivoclar Vivadent, Schaan, Liechtenstein), with the light of wavelength from $380 \mathrm{~nm}$ to $515 \mathrm{~nm}$, and the intensity of polymerisation $1200 \mathrm{mV} / \mathrm{cm}^{2}$.

The microstructure was examined by scanning electron microscope - SEM (JEOL JSM - 5610, JEOL, Tokyo, Japan) with attached EDXS detector (Gresham Scientific Instruments Ltd., Model No.: Sirius 10/SUTW). The accelerating voltage of the electrons was $20 \mathrm{~V}$. Before that, the samples were prepared metallographically by grinding and polishing, and then sputter-coated with carbon (Vacuum Evaporator, Type JEE-SS; Japan Electron Optics, Tokyo, Japan).

The compressive strength was measured with a thermo-mechanical simulation Gleeble 1500D (NY, USA) according to the standard ASTM D3410 / D3410M - 16. ${ }^{11}$ Hardness was measured on Shimadzu Vickers hardness tester (Tokyo, Japan), using a constant indentation load of $1 \mathrm{~kg}$ and a time of indentation of 10 seconds according to the standard EN ISO 6507-1:2018. ${ }^{12}$ Thermal conductivity was measured with a kapton sensor on a Thermal Constant Analyser Hot disc TPS 2200 (Gothenburg, Sweden). Following preliminary tests, we read the results at a setting of $55 \mathrm{mV}$ and a time of 40 seconds.

\section{RESULTS AND DISCUSSION}

The microstructure of the dental composite is shown in Figure 1. The inorganic fillers are clearly visible. The size of these particles is approximately $1 \mu \mathrm{m}$. On this image, the cross mark (Site 1) and the rectangle (Site 2) indicate the areas where the EDXS analyses were made. The results of this analysis (Table 1) confirmed that the bright particle (Site 1) contained a large amount of ytterbium and some fluorine, representing the particles of ytterbium fluoride $\left(\mathrm{YbF}_{3}\right)$. Further EDXS mapping confirmed the overlapping of ytterbium and fluorine in the bright particles (Figure 2). Ytterbium fluoride is the radiopaque agent in the dental material since ytterbium has a high atomic number $(z=71) .{ }^{13}$ On X-ray images, the filling material must be clearly visible and undoubtedly distinguishable from the dental tissues, enabling a dentist to detect any voids or defects in the composite materials. ${ }^{14,15}$ Also, ytterbium fluoride has antibacterial effect due to the release of fluorine. ${ }^{8}$ In the dark area (Figure 1, Site 2) especially high weight percentages of barium and silicon were found. In this area particles of glass components were present, composed of different oxides: $\mathrm{BaO}, \mathrm{SiO}_{2}$ and $\mathrm{Al}_{2} \mathrm{O}_{3}$ (Table 1, Site 2). With the EDXS analysis, organic resin could not be identified.

Table 1: The results of EDXS analysis in $w / \%$

\begin{tabular}{|c|c|c|c|c|c|c|c|}
\hline Site & $\mathrm{O}$ & $\mathrm{Al}$ & $\mathrm{Si}$ & $\mathrm{Ca}$ & $\mathrm{Ba}$ & $\mathrm{Yb}$ & $\mathrm{F}$ \\
\hline 1 & 3.8 & - & 26.7 & - & 11.2 & 67.9 & 6.5 \\
\hline 2 & 8.2 & 7.1 & 40.3 & 0.4 & 43.9 & - & - \\
\hline
\end{tabular}
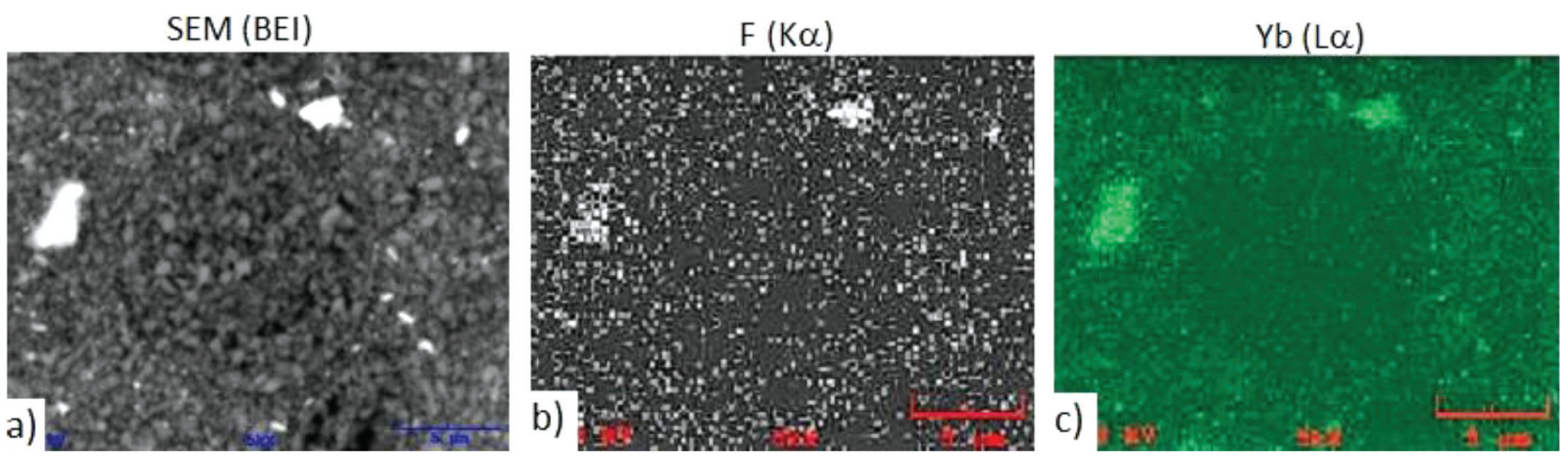

Figure 2: EDXS maps of the dental composite: a) BE image, b) fluorine and c) ytterbium 

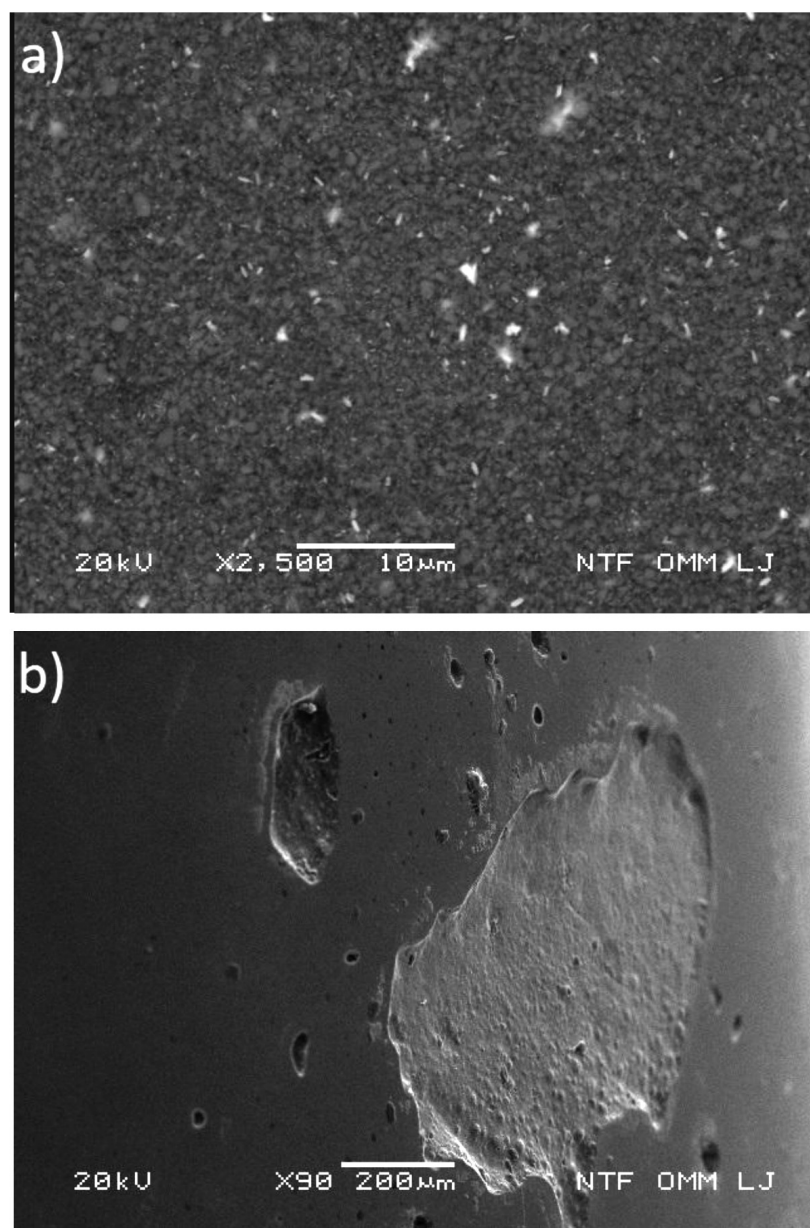

Figure 3: Surface of the sample of dental composite: a) compact and dense surface of the dental composite (BEI), b) some voids due to insufficient condensation of the composite material in narrow glass tube at the time of sample preparation (SEI)

From the SEM micrograph in Figure 3a it can be clearly seen that the dental composite on the surface is compact and dense after polymerisation. However, on the surfaces of both composite cylinder samples, regardless of which polymerisation protocol has been used, as explained in Experimental, some voids were seen (Figure 3b). The reason for this is the application of the composite material into a glass tube with an inner diameter of $8.65 \mathrm{~mm}$, making the sample more than 10 $\mathrm{mm}$ high, which prevents sufficient condensation of the material.

The results of the compression tests, which were made with Gleeble, are presented in Figure 4. It was shown that the sample, prepared by polymerisation in the multiple layers, possessed a much higher compressive strength (180 MPa) than the sample polymerised at the surface of the whole bulk of the composite (65 MPa). Most likely, the explanation could be in the incomplete polymerization of the resin monomers in the inner parts of the composite sample, which was applied in a single piece. In dental restoration, the lack of a cure of the composite can cause fracture of the filling. In all the
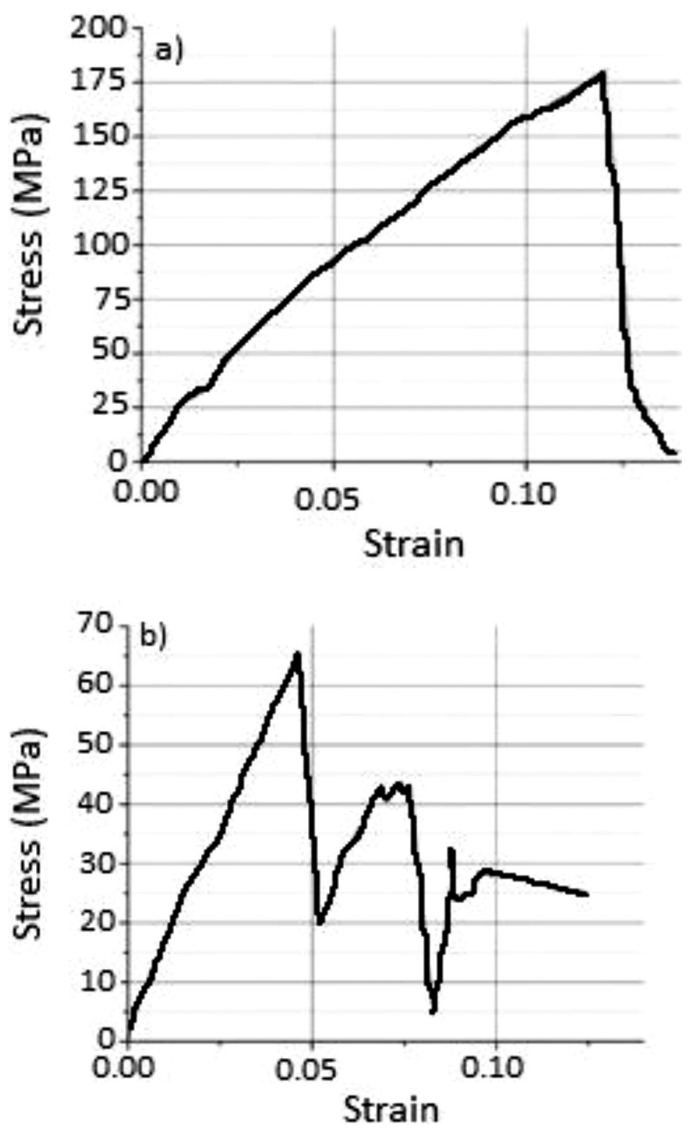

Figure 4: Compressive stress vs. compressive strain curve; a) sample prepared by polymerisation of multiple layers and b) sample prepared by polymerisation of the entire bulk of composite sample

light-activated composites, polymerisation depends on the light's ability to access and initiate the curing in all parts of the composite material. The depth of cure is limited; a depth of greater than $2 \mathrm{~mm}$ should be avoided, and the time of curing should be 30-60 s. Curing for longer than $60 \mathrm{~s}$, however, is not a means of getting greater depths of cure. In any case, the chewing forces on the tooth surface can reach up to $50 \mathrm{MPa} .{ }^{16}$

The measured hardness of both composite samples was on average $120 \mathrm{HV} 1$, which was somewhat lower than the hardness of amalgam (148 HV1). Hardness is a measure of the resistance to localized plastic deformation, and up to a point, hardness is also a good indicator of the wear resistance. In the oral environment, material can be affected by abrasive wear (as two surfaces rub together, and the harder of the two materials may indent or cut out material from the other surface), fatigue wear (as the repeated loading of teeth causes cyclic stresses that in time result in fatigue cracks), and/or corrosive wear (i.e., chemical attack on the material; in composites occur as the hydrolytic decomposition of the resin). Yet it is considered that the best measure of the wear resistance of a composite is its clinical performance. ${ }^{9}$

The measured thermal conductivity of the dental composite sample was $0.52 \mathrm{~W} /(\mathrm{m} \cdot \mathrm{K})$, which is very 
similar to the thermal conductivity of dentine $\left(0.48 \mathrm{~W} /(\mathrm{m} \cdot \mathrm{K}) .{ }^{17}\right.$ For comparison, we also measured the thermal conductivity of the amalgam, which was $23.0 \mathrm{~W} /(\mathrm{m} \cdot \mathrm{K})$. The temperature in the oral cavity varies; especially during eating and drinking it can be substantially lower or higher. ${ }^{18}$ A lower thermal conductivity is of great advantage to maintain healthy tissues of the oral cavity and to prevent an adverse reaction (e.g., the thermal sensitivity of the dental pulp).

\section{CONCLUSIONS}

In dentistry, today the use of composites is very frequent. Dental composites have become more and more popular since they are non-toxic, and exhibit good aesthetic and mechanical properties. Furthermore, their course of polymerisation is predictable and the curing time is suitable. In this study microstructural characterisation as well as some of the mechanical and physical properties (compressive strength, hardness and thermal conductivity) of a nano-filled dental composite was analysed.

The results of the microstructure observation of the dental composite showed that it was composed of two basic components: organic resin and inorganic fillers. The latter was further analysed for chemical composition; it was found that the light particles contained ytterbium fluoride $\left(\mathrm{YbF}_{3}\right)$ and the dark particles were composed of different oxides $\left(\mathrm{BaO}, \mathrm{SiO}_{2}\right.$ and $\left.\mathrm{Al}_{2} \mathrm{O}_{3}\right)$.

The compressive test showed that the sample prepared by polymerisation in multiple layers exhibited a much higher compressive strength $(180 \mathrm{MPa})$ in comparison to the sample polymerised across the surface of the composite sample, previously applied in one piece showing a compressive strength of only $(65 \mathrm{MPa})$.

The measured hardness of the composite was $120 \mathrm{HV}$, which is somewhat lower than the measured hardness of amalgam (147.8 HV).

The thermal conductivity of dental composite was $0.52 \mathrm{~W} /(\mathrm{m} \cdot \mathrm{K})$, while that of the amalgam was $23.0 \mathrm{~W} /(\mathrm{m} \cdot \mathrm{K})$.

In conclusion, materials that are used for the substitution of hard dental tissues are exposed to specific conditions in the mouth (acid environment, strong masticatory forces, fluctuations in temperature). Therefore, such materials must possess the capability to successfully pass those changes. Based on the presented study the analysed dental composite meets clinical requirements for use as a dental restorative material.

\section{REFERENCES}

${ }^{1}$ D. Stamenković, K. Obradović-Đuričić, V. Ivanović, Z. Vulićević, D. Marković, A. Todorović, K. Raić, G. Pavlović, G. Popović, S. Veličković, Stomatološki materijali: knjiga 1. ed. Stomatološki fakultet u Beogradu, Beograd 2009, 584

2 J. L. Ferracane, Resin composite - State of the art, Dental materials, 27 (2011), 29-38

${ }^{3}$ K. D. Jandt, B. W. Sigusch, Future perspective of resin-based dental materials, Dental materials, 25 (2009), 1001-1006

${ }^{4}$ R. K. Ravi, R. K, Alla, M. Shammas, A. Devarhubli, Dental Composites - A Versatile Restorative Material: An Overview, Indian Journal of Dental Sciences, 5 (2013) 5, 111-115

${ }^{5}$ B. Zimmerli, M. Strub, F. Jeger, O. Stadler, A. Lussi, Composite materials: Composition, properties and clinical application, Schweiz Monatschritt. Zahnmed., 120 (2010), 972-979

${ }^{6}$ X. Wang, G. Huyang, S. V. Palagummi, X. Liu, D. Skrtic, C. Beauchamp, R. Bowen, J. Sun, High performance dental resin composites withhydrolytically stable monomers, DentalMaterials, 34 (2018), 228-237

${ }^{7}$ N. Moszner, U. Salz, New development of polymeric dental composites, Prog. Polym. Sci., 26 (2001) 4, 535-576

${ }^{8}$ N. Beyth, S. Farah, A. J. Domb, E. I. Weiss, Antibacterial dental resin composites, Reactive \& Functional Polymers, 75 (2014), 81-88

${ }^{9}$ R. G. Craig, J. M. Powers, Restorative dental materials $11^{\text {th }}$ ed. Mosby, 2002, 704

${ }^{10}$ B. Karpe, M. Vodlan, I. Kopač, I. Budak, A. Nagode, A. Pavlič, T. Puškar, B. Kosec, Thermal properties of materials used in dental medicine, Journal of Advanced Technologies and Materials, 43 (2018) 1, 1-4

${ }^{11}$ Standard Test Method for Compressive Properties of Polymer Matrix Composite Materials with Unsupported Gage Section by Shear Loading, ASTM D3410 / D3410M - 16

${ }^{12}$ Metallic materials - Vickers hardness test - Part 1: Test method, EN ISO 6507-1:2018

${ }^{13}$ J. L. Adam, Fluoride glass research in France: fundamentals and applications, Journal of Fluorine Chemistry, 107 (2001), 265-70

${ }^{14}$ F. M. Collares, F. A. Ogliari, G. S. Lima, V. R. C. Fontanella, E. Piva, S. M. W. Samuel Ytterbium trifluoride as a radiopaque agent for dental cements, International Endodontic Journal, 43 (2010) 9, 792-797

${ }^{15}$ N. L. V. Carreno, T. C. S. Oliveira, E. Piva, F. B. Leal, G. S. Lima, M. D. Moncks, C. W. Raubach, F. A. Ogliari, YbF3/SiO2 Fillers as Radiopacifiers in A Dental Adhesive Resin, Nano-Micro Letters, 4 (2012), 3, 189-196

${ }^{16}$ V. Jerolimov, Osnove stomatoloških materijala, Stomatološki fakultet Sveučilišta u Zagrebu, Zagreb 2015), 281

${ }^{17}$ M. Lin, Q. D. Liu, T. Kim, T. Xu, B. F. Bai, T. J. Lu, A new method for characterization of thermal properties of human enamel and dentine: Influence of microstructure, Infrared Physics \& Technology, 53 (2010), 457-463

${ }^{18}$ I. Štefanec, Kompozitni materiali u stomatologiji, Polimeri, 32 (2011) 3-4, 136-138 